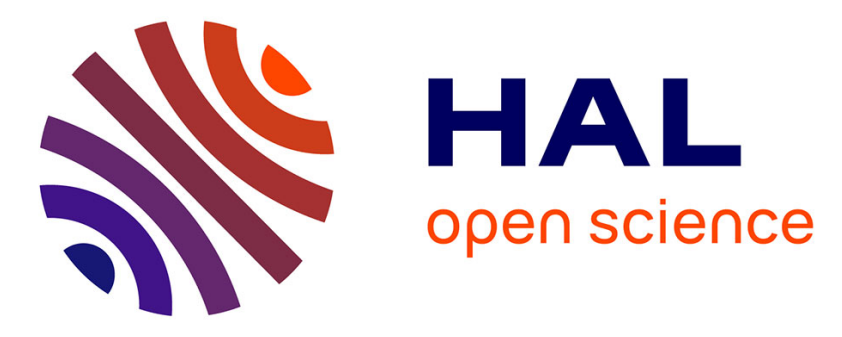

\title{
Alkali-glass behavior in honeycomb-type layered Li3-xNaxNi2SbO6 solid solution
}

Coélio Vallée, Matthieu Saubanère, Paula Sanz Camacho, Yohan Biecher, Bernard Fraisse, Emmanuelle Suard, Gwenaelle Rousse, Dany Carlier, Romain Berthelot

\section{To cite this version:}

Coélio Vallée, Matthieu Saubanère, Paula Sanz Camacho, Yohan Biecher, Bernard Fraisse, et al.. Alkali-glass behavior in honeycomb-type layered Li3-xNaxNi2SbO6 solid solution. Inorganic Chemistry, 2019, 58 (17), pp.11546-11552. 10.1021/acs.inorgchem.9b01385 . hal-02289822

\section{HAL Id: hal-02289822 https://hal.science/hal-02289822}

Submitted on 30 Jun 2020

HAL is a multi-disciplinary open access archive for the deposit and dissemination of scientific research documents, whether they are published or not. The documents may come from teaching and research institutions in France or abroad, or from public or private research centers.
L'archive ouverte pluridisciplinaire HAL, est destinée au dépôt et à la diffusion de documents scientifiques de niveau recherche, publiés ou non, émanant des établissements d'enseignement et de recherche français ou étrangers, des laboratoires publics ou privés. 
Alkali-glass behavior in honeycomb-type layered $\mathrm{Li}_{3-x} \mathrm{Na}_{x} \mathrm{Ni}_{2} \mathrm{SbO}_{6}$ solid-solution

Coélio Vallée, ${ }^{1}$ Matthieu Saubanère, ${ }^{1,2}$ Paula Sanz-Camacho, ${ }^{2,3}$ Yohan Biecher ${ }^{2,3}$ Bernard Fraisse ${ }^{1}$ Emmanuelle Suard, ${ }^{4}$ Gwenaëlle Rousse, ${ }^{2,5,6}$ Dany Carlier ${ }^{2,3}$, Romain Berthelot, ${ }^{1,2, *}$

1 : ICGM, Université de Montpellier, CNRS, Montpellier 34095, France

2 : Réseau sur le Stockage Électrochimique de l'Énergie (RS2E), CNRS, Amiens, France

3 : ICMCB, Université de Bordeaux, CNRS, Pessac 33608, France

4 : Institut Laue-Langevin (ILL), BP 156, 71 Avenue des Martyrs, 38042 Grenoble cedex 9, France

5 : Chimie du Solide et de l'Energie, UMR 8260, Collège de France, 11 place Marcelin Berthelot, 75231 Paris Cedex 05, France.

6 : Sorbonne Université, 4 Place Jussieu, F-75005 Paris, France

\section{Corresponding author:}

Dr. Romain Berthelot: romain.berthelot@umontpellier.fr

\section{Keywords:}

Layered oxides, honeycomb ordering, solid-solution, alkali mixed occupancy 


\begin{abstract}
Layered oxides compositions $\mathrm{Li}_{3-\mathrm{x}} \mathrm{Na}_{\mathrm{x}} \mathrm{Ni}_{2} \mathrm{SbO}_{6}$ have been prepared by solid-state synthesis. $\mathrm{A}$ complete solid-solution is evidenced and characterized by X-ray and neutron diffraction, as well as ${ }^{7} \mathrm{Li}$ and ${ }^{23} \mathrm{Na}$ solid-state nuclear magnetic resonance spectroscopy. The transition metal layer is characterized by the classic honeycomb $\mathrm{Ni}^{2+} / \mathrm{Sb}^{5+}$ ordering, while a more uncommon randomly mixed occupancy of lithium and sodium is evidenced within the alkali interslab space. In situ X-ray diffraction and DFT calculations show that this alkali disordered feature is entropically driven. Fast cooling appears then as a synthesis root to confine bidimensional alkali glass within crystalline layered oxides.
\end{abstract}

\title{
Graphical abstract / TOC graphic
}

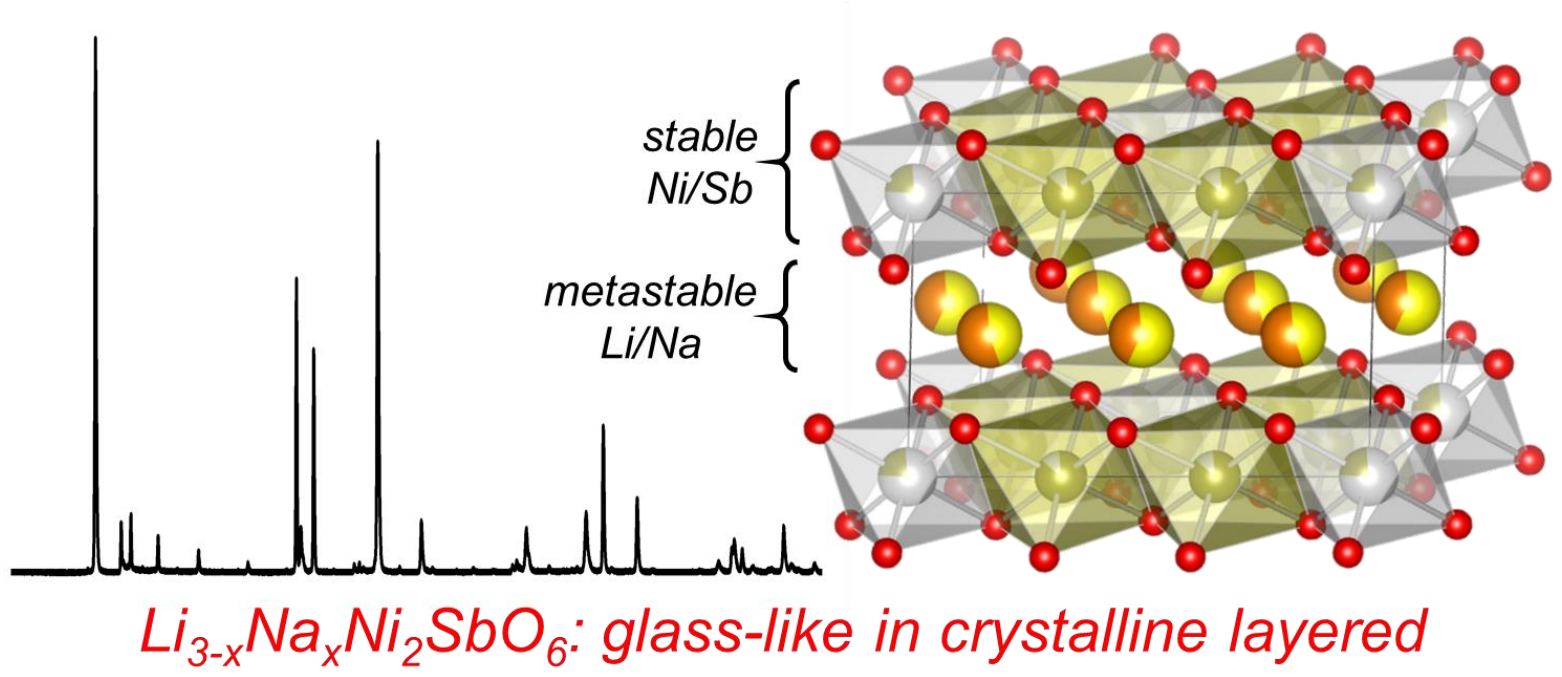

\section{TOC synopsis}

Structural refinement and solid-state NMR validates a complete solid-solution for honeycombtype layered oxides $\mathrm{Li}_{3-x} \mathrm{Na}_{x} \mathrm{Ni}_{2} \mathrm{SbO}_{6}$. An uncommon randomly mixed occupancy of lithium and sodium is evidenced within the alkali interslab space, this feature being entropically driven. 
Fast cooling appears then as a synthesis root to create alkali glass layer within crystalline layered oxides.

\section{Introduction}

Ionic radii of lithium and sodium cations are significantly different in chalcogenides or halides. ${ }^{1}$ As a consequence, there are in literature very few cases of mixed lithium/sodium occupancy in same crystallographic sites in transition metal oxides. Examples are vanadates $\mathrm{Li}_{1-x} \mathrm{Na}_{x} \mathrm{VO}_{3}{ }^{2}$ or bronzes $\mathrm{Li}_{x} \mathrm{Na}_{y} \mathrm{~V}_{3} \mathrm{O}_{8}$, the latter being widely investigated as insertion-type negative electrode materials for rechargeable lithium-ion batteries, ${ }^{3}$ or niobiates perovskites $\mathrm{Li}_{1-x} \mathrm{Na}_{x} \mathrm{NbO}_{3}$ with piezoelectric properties. ${ }^{4-6}$ Regarding the important family of alkali transition metal layered oxides, the crystallographic structure offers a large playground for solid-state chemists and physicists due to the impressive richness of chemical compositions that can tailor different properties. The lamellar organization is usually described by a stacking of edge-shared $\mathrm{MO}_{6}$ octahedra slabs, with intercalation of alkali ions in the interslab space. Chemical substitutions on the transition metal layers are possible thanks to similar ionic radii in octahedral symmetry for cations, enabling to tune some physical or chemical features. The best example might be the emerging layered compositions $\mathrm{LiNi}_{1-x-y} \mathrm{Co}_{x} \mathrm{Al}_{y} \mathrm{O}_{2}$ or $\mathrm{LiNi}_{1-x-y} \mathrm{Mn}_{x} \mathrm{Co}_{y} \mathrm{O}_{2}$ which exhibit enhanced electrochemical performance compared to the standard electrode material $\mathrm{LiCoO}_{2}{ }^{7-}$

${ }^{9}$ On the contrary, cases of alkali ions mixed occupancy within the interslab spaces are very scarce. To the best of our knowledge, only two examples have been reported, single crystals of rhomboedral titanate $\left(\mathrm{Na}_{0.73} \mathrm{Li}_{0.24}\right)\left(\mathrm{Li}_{0.32} \mathrm{Ti}_{0.68}\right) \mathrm{O}_{2}$ studied by Nalbandyan, ${ }^{10}$ and nickelates $\mathrm{Li}_{1-x} \mathrm{Na}_{x} \mathrm{NiO}_{2}$ investigated separately by Matsumura and Holzapfel in early 2000 s. ${ }^{11-13}$

In the frame of discovering new layered dual-alkali transition metal layered oxides with possible interesting physical features, this work investigates intermediate compositions 
between $\mathrm{Li}_{3} \mathrm{Ni}_{2} \mathrm{SbO}_{6}$ and $\mathrm{Na}_{3} \mathrm{Ni}_{2} \mathrm{SbO}_{6}$ (or $\mathrm{LiNi}_{2 / 3} \mathrm{Sb}_{1 / 3} \mathrm{O}_{2}$ and $\mathrm{NaNi}_{2 / 3} \mathrm{Sb}_{1 / 3} \mathrm{O}_{2}$, respectively). These compounds are structurally related to $\mathrm{O} 3$-type ${ }^{14} \mathrm{LiCoO}_{2}$, with an additional honeycombtype ordering of the $\mathrm{Ni}^{2+}$ and $\mathrm{Sb}^{5+}$ cations. ${ }^{15-18} \mathrm{~A}$ complete solid-solution could be obtained by ceramic route one-pot synthesis from carbonates or oxides precursors. The lithium/sodium mixed occupancy is confirmed by structural refinement and solid-state NMR spectroscopy. The alkali ions random distribution is not thermodynamically stable as decomposition is observed by in situ XRD during either heating or slow cooling. These results pave the way to design crystalline layered compounds with 2D confined alkali glass.

\section{Experimental section}

$\mathrm{Li}_{3} \mathrm{Ni}_{2} \mathrm{SbO}_{6}, \mathrm{Na}_{3} \mathrm{Ni}_{2} \mathrm{SbO} 6$ and intermediate compositions $\mathrm{Li}_{3-\mathrm{x}} \mathrm{Na}_{\mathrm{x}} \mathrm{Ni}_{2} \mathrm{SbO}_{6}(0 \leq \mathrm{x} \leq 3)$ have been prepared by conventional solid-state synthesis. Dried alkali carbonates $\left(\mathrm{Li}_{2} \mathrm{CO}_{3}\right.$, Aldrich, $99.997 \%$ or $\mathrm{Na}_{2} \mathrm{CO}_{3}$, Sigma-Aldrich, $99.5 \%$ ) are thoroughly mixed with nickel and antimony oxides ( $\mathrm{NiO}$, Prolabo and $\mathrm{Sb}_{2} \mathrm{O}_{3}$, Merck, $99 \%$ ), with a nominal alkali excess of 5-10 wt.\% to compensate the high-temperature volatility. The resulting mixtures are then pelletized and heated for 5 hours at $900{ }^{\circ} \mathrm{C}$ in air on a platinum crucible. A rapid quench in oil bath ends the heat treatment, and the resulting pellets are then washed with ethanol and dried before storage. X-ray diffraction (XRD) was performed on a Bruker D8 Discovery diffractometer with $\mathrm{K} \alpha 1 \mathrm{Cu}$ radiation, from 5 to $120^{\circ}$ ( $16 \mathrm{~h}$ of total scan). Sample powders were sieved below $100 \mu \mathrm{m}$ for analysis. Moreover, the thermal stability of the samples was followed in situ by XRD on a PANalytical Empyrean with $\mathrm{K} \alpha \mathrm{Co}$ radiation and equipped with an Anton Paar heating chamber.

Neutron powder diffraction (ND) was carried out at room temperature out at Institut Laue Langevin on D2B high resolution powder diffractometer (1.594 A wavelength). For that, $3 \mathrm{~g}$ of 
as-prepared powder of the composition $\mathrm{Li}_{1.5} \mathrm{Na}_{1.5} \mathrm{Ni}_{2} \mathrm{SbO}_{6}$ have been sealed in a cylindrical vanadium tube.

${ }^{23} \mathrm{Na}$ MAS NMR spectra were recorded on a Bruker 300 Avance spectrometer at $79.49 \mathrm{MHz}$ (7.05 T magnet) using a standard Bruker 2.5 MAS probe at a spinning frequency of $30 \mathrm{kHz}$ and a recycle time $D_{0}=0.5 \mathrm{~s}$, long enough to avoid $T_{1}$ saturation effects. A one rotor period synchronized Hahn echo sequence was used with a $90^{\circ}$ pulse length of $1.5 \mu$ s. The external reference was a 1 mol.L $\mathrm{L}^{-1} \mathrm{NaCl}$ aqueous solution. ${ }^{7} \mathrm{Li}$ MAS NMR spectra were recorded on a Bruker Avance III spectrometer at 38.93 MHz (2.35 T magnet), a standard Bruker 2.5 MAS probe at a $30 \mathrm{kHz}$ spinning frequency. A Hahn echo sequence was used with a $90^{\circ}$ pulse of $1.6 \mu$ s with a relaxation time of $1 \mathrm{~s}$. The $0 \mathrm{ppm}$ external reference was a $1 \mathrm{M} \mathrm{LiCl}$ aqueous solution.

Density functional theory calculation $(\mathrm{DFT}+\mathrm{U})$ used the monoclinic description of Zvereva ${ }^{18}$ with two alkali layers ( $C 2 / m$ space group) as starting point. About hundred different crystallographic structures have been generated with a random distribution of lithium and sodium ions over the 24 available positions. All structures have been fully relaxed using the plane wave code "Vienna Ab-Initio Simulation Package" with PAW pseudo-potentials and the PBE functional. ${ }^{19-21} \mathrm{~A} \mathrm{U}_{\text {eff }}=4 \mathrm{eV}$ is considered to take into account electron-electron interactions on nickel. ${ }^{22}$ The forces on the atoms were converged to $510^{-3} \mathrm{eV} / \AA$ with a planewave energy cut-off of $600 \mathrm{eV}$ and a well converged set of K-points. 


\section{Results and Discussion}

\section{An alkali ions mixed occupancy}

XRD patterns obtained with a final quenching at the end of the thermal treatment are gathered in Figure 1a for all compositions from $\mathrm{Li}_{3} \mathrm{Ni}_{2} \mathrm{SbO}_{6}$ to $\mathrm{Na}_{3} \mathrm{Ni}_{2} \mathrm{SbO}_{6}$. No extra peak could be assigned to impurities like binary oxides or alkali hydroxides, and the patterns could be indexed using the monoclinic symmetry (space group $C 2 / m$ ). In comparison with a classic O3-type stacking ( $\alpha-\mathrm{NaFeO}_{2}$ polytype), the $\mathrm{Ni}^{2+} / \mathrm{Sb}^{5+}$ honeycomb ordering induces superstructure peaks visible in the $19-32{ }^{\circ} 2 \theta$ region. They can be nicely observed in Figure $1 \mathrm{~b}$, with for Li-rich compositions a broadening that is reminiscent of stacking faults, as commonly observed in such honeycomb-ordered lamellar oxides. ${ }^{15-17}$

The refined cell parameters evolve regularly all along the chemical compositions, following a classical Vegard's law (Figure S1). The evolution of the corresponding monoclinic cell volume shown in inset of Figure 1c demonstrates a complete solid-solution behavior from $\mathrm{Li}_{3} \mathrm{Ni}_{2} \mathrm{SbO}_{6}$ to $\mathrm{Na}_{3} \mathrm{Ni}_{2} \mathrm{SbO}_{6}$. The question arising from this assumption is the localization of both lithium and sodium cations. Three structural models seem possible. They are pictured in Figure 2 for the particular compositions $\mathrm{Li}_{1.5} \mathrm{Na}_{1.5} \mathrm{Ni}_{2} \mathrm{SbO}_{6}$. The first one is a mixed occupancy of lithium and sodium ions and a random in-plane distribution within. Following the structural description of Zvereva ${ }^{18}$ and $\mathrm{Ma}^{17}$, the slab thickness (basically including one transition metal and one alkali layers) is $4.856 \AA$ and $5.344 \AA$ for $\mathrm{Li}_{3} \mathrm{Ni}_{2} \mathrm{SbO}_{6}$ and $\mathrm{Na}_{3} \mathrm{Ni}_{2} \mathrm{SbO}_{6}$. From lithium-rich to sodium-rich end members, the increase is about $10 \%$ and comes from an important enhancement of the alkali layer (from $2.60 \AA$ to $3.21 \AA$, hence $+23.5 \%$ ) whereas the transition metal layer is slightly contracted. In our case, the linear evolution of the slab thickness also shows an increase of about $10 \%$ (Figure 1d) and consequently supports this structural assumption. 
In the second model, lithium and sodium ions always occupy the same interslab space but following an in-plane ordering (either chains, stripes, cluster, etc.). The last model also lies on alkali ions ordering, lithium and sodium ions occupy distinct interslab spaces. For the intermediate composition $\mathrm{Li}_{1.5} \mathrm{Na}_{1.5} \mathrm{Ni}_{2} \mathrm{SbO}_{6}$, such arrangement would result in alternate $\mathrm{Li}^{+} / \mathrm{Na}^{+}$layers, as it has been already evidenced for the unique case of OP4- $\mathrm{Li}_{\mathrm{x}} \mathrm{Na}_{\mathrm{y}} \mathrm{CoO}_{2}{ }^{23} \mathrm{It}$ is important to point out that, in the two latter models, the mean slab thickness evolution (determined from the out-of-plane $c$ parameter) could be also assumed.

In alkali transition metal layered oxides, alkali cations out-of-plane ordering like in OP4- $\mathrm{Li}_{\mathrm{x}} \mathrm{Na}_{\mathrm{y}} \mathrm{CoO}_{2}$ or alkali cations / vacancies in-plane ordering like in $\mathrm{Na}_{1 / 2} \mathrm{CoO}_{2}$ or $\mathrm{K}_{4 / 7} \mathrm{CoO}_{2}$ lead to significant superstructure peaks in X-ray diffraction pattern. ${ }^{23-25}$ The two last abovementioned models involve cationic ordering and the corresponding simulated patterns clearly evidence superstructure peaks (Figure S2). The absence of such peak in our highresolution XRD pattern in Figure 1 is a first clue to discard these two hypotheses and consequently to support the model of random $\mathrm{Li} / \mathrm{Na}$ distribution despite their different ionic radii (0.76 and $1.02 \AA$ in octahedral symmetry, respectively). ${ }^{1}$

In order to get local information on lithium and sodium environments, solid-state NMR has been further carried out for all the compositions, and corresponding ${ }^{7} \mathrm{Li}$ and ${ }^{23} \mathrm{Na}$ spectra are shown in Figure 3. The peak shifts for all compounds results from the Fermi contact interaction between the paramagnetic low spin $\mathrm{Ni}^{2+}\left(\mathrm{t}_{2 \mathrm{~g}}{ }^{6} \mathrm{eg}_{\mathrm{g}}{ }^{2}\right)$ ions and the probed nucleus. This interaction occurs through the chemical bonds and therefore denotes the local electronic structure. Whatever the structural hypotheses presented above, the two alkaline $\mathrm{A}^{+}$ions in the system are surrounded by four $\mathrm{Ni}^{2+}$ as first cation neighbors $\left(90^{\circ} \mathrm{A}-\mathrm{O}-\mathrm{Ni}\right.$ interaction $)$ and four $\mathrm{Ni}^{2+}$ as second cation neighbors ( $180^{\circ} \mathrm{A}-\mathrm{O}-\mathrm{Ni}$ interaction) with slightly different distances and angles. 
For $\mathrm{Li}_{3} \mathrm{Ni}_{2} \mathrm{SbO}_{6}$, two distinct narrow peaks at 492 and $420 \mathrm{ppm}$ and a larger set of signals around $300 \mathrm{ppm}$ are observed by ${ }^{7} \mathrm{Li}$ MAS NMR. According to the literature, based on their relative intensities, the two first are assigned to lithium ions respectively in $2 d$ and $4 h$ Wyckoff positions of the space group $C 2 / m$, i.e. within the interslab space in octahedral insertion sites. The third broad contribution around 300 ppm could be assigned to stacking defects, similarly to stacking faults observation in the $\mathrm{Li}_{2} \mathrm{MnO}_{3}$ reported by Grey and coworkers. ${ }^{26}$ Indeed, the relative intensity of the contribution at 300 ppm compared to the two other sharp peaks depends on the synthesis conditions: when $\mathrm{Li}_{3} \mathrm{Ni}_{2} \mathrm{SbO}_{6}$ is prepared with a final slow cooling, the two first peaks are clearly sharper and the broad contribution almost disappear (Figure S3). On the opposite side of the Figure $3,{ }^{23} \mathrm{Na} \mathrm{NMR}$ spectrum for $\mathrm{Na}_{3} \mathrm{Ni}_{2} \mathrm{SbO}_{6}$ exhibits two contributions located at $1440 \mathrm{ppm}$ and $1300 \mathrm{ppm}$ with no second order quadrupolar lineshape, contrary to the spectrum reported by Ma et al. using a lower magnetic field (200 MHz spectrometer) and a higher spinning frequency $(50 \mathrm{KHz}) \cdot{ }^{17}$ Based on the relative peak intensities, we can also assign those two peaks to $\mathrm{Na}$ ions in the in $2 d$ and $4 h$ sites respectively. Interestingly, the difference between quenched and non-quenched $\mathrm{Na}_{3} \mathrm{Ni}_{2} \mathrm{SbO}_{6}$ is very weak as both XRD pattern and NMR data look very similar (Figure S4). Thanks to higher weight and larger ionic radii of sodium compare to lithium and in agreement with the observation of superstructure peaks shapes in inset of Figure $1, \mathrm{Na}_{3} \mathrm{Ni}_{2} \mathrm{SbO}_{6}$ seems to ordered more easily than $\mathrm{Li}_{3} \mathrm{Ni}_{2} \mathrm{SbO}_{6}$ and is therefore less sensitive to quenching.

Intermediate compositions $\mathrm{Li}_{3-\mathrm{x}} \mathrm{Na}_{\mathrm{x}} \mathrm{Ni}_{2} \mathrm{SbO}_{6}$ can be analyzed by both ${ }^{7} \mathrm{Li}$ and ${ }^{23} \mathrm{Na} \mathrm{NMR}$. At a first glance, broader resonance peaks are clearly evidenced. In both cases, the broadness increases when compositions moves away from $\mathrm{Li}_{3} \mathrm{Ni}_{2} \mathrm{SbO}_{6}$ or $\mathrm{Na}_{3} \mathrm{Ni}_{2} \mathrm{SbO}_{6}$. Moreover, a weak but significant peak shift also accounts for variation of the $(\mathrm{Li}-\mathrm{O}$ and $\mathrm{Na}-\mathrm{O})$ interatomic distances. Shifting toward lower ppm in ${ }^{7} \mathrm{Li}$ NMR spectra corresponds to a decrease of the electronic spin transfer from low spin $\mathrm{Ni}^{2+}$ to $\mathrm{Li}$ nuclei that can be attributed to an increase of 
the $\mathrm{Li}-\mathrm{O}$ distances, whereas displacement to higher ppm in ${ }^{23} \mathrm{Na} \mathrm{NMR}$ spectra is attributed to a decreasing of the $\mathrm{Na}-\mathrm{O}$ distances. Therefore, the NMR study tends to demonstrate that the alkali layers in $\mathrm{Li}_{3-\mathrm{x}} \mathrm{Na}_{\mathrm{x}} \mathrm{Ni}_{2} \mathrm{SbO}_{6}$ compositions do not correspond to an intergrowth of pure $\mathrm{Li}$ and $\mathrm{Na}$ layers but do contain both alkaline ions. Indeed, sodium ions present in a Li layer will increase the local Li-O distance compared to $\mathrm{Li}_{3} \mathrm{Ni}_{2} \mathrm{SbO}_{6}$ and lithium ions present in the $\mathrm{Na}$ layer will decrease the local $\mathrm{Li}-\mathrm{O}$ distance compared to $\mathrm{Na}_{3} \mathrm{Ni}_{2} \mathrm{SbO}_{6}$. Moreover, the overall broadening of the NMR lines results from a larger distribution of environments as locally distances and angles will vary depending on the amount of surrounding Li/Na ions. In addition, it worth noting the decrease of third contribution at $300 \mathrm{ppm}$ in the ${ }^{7} \mathrm{Li}$ spectra with higher sodium amount. This accounts for less stacking faults for Na-rich compositions, which is logical when stated that $\mathrm{Na}_{3} \mathrm{Ni}_{2} \mathrm{SbO}_{6}$ is less sensitive to quenching than $\mathrm{Li}_{3} \mathrm{Ni}_{2} \mathrm{SbO}_{6}$.

In order to confirm the hypothesis of a random distribution of both lithium and sodium ions in the same interslab space suggested by the NMR analysis, structural refinements have been performed on high-resolution XRD and neutron powder diffraction patterns data for the particular composition $\mathrm{Li}_{1.5} \mathrm{Na}_{1.5} \mathrm{Ni}_{2} \mathrm{SbO}_{6}$. Indeed with four different chemical species ( $\mathrm{Li}, \mathrm{Na}$, $\mathrm{Ni}, \mathrm{Sb}$ ) possibly distributed among four crystallographic sites ( $2 d$ and $4 h$ in the interslab space, and $2 a$ and $4 g$ in the metal layers), a unique solution cannot be found without $i$ ) combining Xray with neutrons, that offers a nice contrast $\left(b_{N i}=+10.3 \mathrm{fm}, b_{S b}=+5.57 \mathrm{fm}, b_{L i}=-1.90 \mathrm{fm}\right.$, $\mathrm{b}_{\mathrm{Na}}=+3.63 \mathrm{fm}$ ), and ii) imposing some constraints that are detailed as follows. We used as a starting model the $C 2 / m$ monoclinic structural description of $\mathrm{Li}_{3} \mathrm{Ni}_{2} \mathrm{SbO}_{6}$ by Zvereva et al. ${ }^{27}$ The total number of $\mathrm{Li}, \mathrm{Na} \mathrm{Ni}$ and $\mathrm{Sb}$ was imposed to the nominal composition, with $\mathrm{Li}$ and $\mathrm{Na}$ being distributed on the $2 d$ and $4 h$ sites, and $\mathrm{Ni}$ and $\mathrm{Sb}$ on the $2 a$ and $4 g$ sites. All atomic positions and the relative occupancy of $\mathrm{Li} / \mathrm{Na}$ and $\mathrm{Ni} / \mathrm{Sb}$ were freely refined. An isotropic temperature factor was refined and imposed equal for a same chemical species/Wyckoff site. 
The result of the combined XRD/neutron refinement is shown in Figure 4 and the corresponding table of atomic positions and resulting structure are presented in Table 1 and Figure 5, respectively. Although the overall $\mathrm{Ni} / \mathrm{Sb}$ honeycomb pattern is confirmed within the transition metal slab with $4 g$ and $2 a$ sites mainly occupied by $\mathrm{Ni}$ and $\mathrm{Sb}$, respectively; a certain $\mathrm{Ni} / \mathrm{Sb}$ mixing is obtained in the structural refinement. Because the relative occupancies of $\mathrm{Ni}$ and $\mathrm{Sb}$ were not refined in previous structural refinement, this relative disorder was not reported in $\mathrm{Li}_{3} \mathrm{Ni}_{2} \mathrm{SbO}_{6}$ and $\mathrm{Na}_{3} \mathrm{Ni}_{2} \mathrm{SbO}_{6}$. As stacking faults characterized quenched layered samples, it is reasonable to assume that the high value of $\mathrm{Ni} / \mathrm{Sb}$ mixing is over-estimated, as reported for a similar lamellar compound $\mathrm{Li}_{4} \mathrm{FeSbO}_{6} .{ }^{28}$ For comparison, structural refinement for quenched $\mathrm{Li}_{3} \mathrm{Ni}_{2} \mathrm{SbO}_{6}$ and $\mathrm{Na}_{3} \mathrm{Ni}_{2} \mathrm{SbO}_{6}$ from $\mathrm{ND}$ also ends up with some $\mathrm{Ni} / \mathrm{Sb}$ mixing. Interestingly the $\mathrm{Ni} / \mathrm{Sb}$ mixing regularly increases from $\mathrm{Li}_{3} \mathrm{Ni}_{2} \mathrm{SbO}_{6}$ to $\mathrm{Na}_{3} \mathrm{Ni}_{2} \mathrm{SbO}_{6}$ (Figure $\mathrm{S} 5$ and Table $\mathrm{S} 1$ ).

Regarding the interlayer space, the alkali layer is occupied by both lithium and sodium cations and the refinement indicates a $\mathrm{Li} / \mathrm{Na}$ mixing very close to the statistical value of $50 \%$. Lithium and sodium cations are therefore randomly distributed and seem to not form any kind of ordering patterns that could be induced by the strong ionic radii difference and/or by the neighbor $\mathrm{Ni} / \mathrm{Sb}$ honeycomb-like ordering. To the best of our knowledge, this is the first example of a complete solid-solution from Li to $\mathrm{Na}$ layered oxide with no structural change and no biphasic domain like for $\mathrm{Li}_{1-\mathrm{x}} \mathrm{Na}_{x} \mathrm{NiO}_{2}{ }^{11-13}$

\section{A glass-like behavior}

After demonstrating the mixing of lithium and sodium despite their very different ionic radii, it was important to investigate the formation process of this very uncommon crystallographic feature. First, it is worth pointing out the influence of the quenching process at the end the 
thermal treatment. Indeed, a slow cooling rate down to room temperature leads to very different XRD patterns, with coexistence of $\mathrm{Li}_{3} \mathrm{Ni}_{2} \mathrm{SbO}_{6}$ and $\mathrm{Na}_{3} \mathrm{Ni}_{2} \mathrm{SbO}_{6}$ as the main phases and with a very weak intermediate contribution from the mixed $\mathrm{Li}_{3-\mathrm{x}} \mathrm{Na}_{\mathrm{x}} \mathrm{Ni}_{2} \mathrm{SbO}_{6}$ (see Figure $\mathrm{S} 3$ for a nominal composition " $\mathrm{Li}_{1.5} \mathrm{Na}_{1.5} \mathrm{Ni}_{2} \mathrm{SbO}_{6}$ "). In their pioneering investigation on layered $\mathrm{Li}_{1-}$ ${ }_{x} \mathrm{Na}_{x} \mathrm{NiO}_{2}$, Matsumura and coworkers also briefly noticed that quenching was mandatory for obtaining a monophasic product. ${ }^{11}$ In this current study, we decided to have much deeper grasp on the details of the stability of the obtained monophasic compositions by combining XRD and DFT approaches.

The thermal evolution of quenched $\mathrm{Li}_{1.5} \mathrm{Na}_{1.5} \mathrm{Ni}_{2} \mathrm{SbO}_{6}$ has been monitored by in situ XRD (Figure 6). At $300{ }^{\circ} \mathrm{C}$, the phase decomposes as its main diffraction peak (001) splits into two peaks accounting for $\mathrm{Li}_{3} \mathrm{Ni}_{2} \mathrm{SbO}_{6}$ and $\mathrm{Na}_{3} \mathrm{Ni}_{2} \mathrm{SbO}_{6}$ domains. At higher temperatures, the synthesis conditions of a monophasic domain are gathered again and the two peaks merge into one contribution accounting for (001) of $\mathrm{Li}_{1.5} \mathrm{Na}_{1.5} \mathrm{Ni}_{2} \mathrm{SbO}_{6}$. During the slow cooling down, a second splitting occurs, showing the reformation of $\mathrm{Li}_{3} \mathrm{Ni}_{2} \mathrm{SbO}_{6}$ and $\mathrm{Na}_{3} \mathrm{Ni}_{2} \mathrm{SbO}_{6}$ domains. This result clearly highlights the role of the final quench for stabilizing at room temperature a monophasic composition with a random distribution of alkali ions in the interslab layer. Such thermal feature strongly recalls the behavior of the layered oxide OP4- $\mathrm{Li}_{x} \mathrm{Na}_{y} \mathrm{CoO}_{2}$, for which lithium and sodium are not randomly mixed but alternately ordered one layer over two in octahedral and prismatic sites, respectively. ${ }^{23}$

Following the peak position evolution of the $\mathrm{Li}_{3} \mathrm{Ni}_{2} \mathrm{SbO}_{6}$ and $\mathrm{Na}_{3} \mathrm{Ni}_{2} \mathrm{SbO}_{6}$ domains can help in understanding the mechanism involved in the formation of a monophasic domain $\mathrm{Li}_{1.5} \mathrm{Na}_{1.5} \mathrm{Ni}_{2} \mathrm{SbO}_{6}$ at high temperature. First, it is important to keep in mind the thermal expansion that significantly increases the slab thickness and thus displaces the (001) peaks towards low angles (i.e. from $20.1^{\circ}$ at room temperature to $19.7^{\circ}$ at $900{ }^{\circ} \mathrm{C}$ for the $(001)$ peak of $\mathrm{Li}_{1.5} \mathrm{Na}_{1.5} \mathrm{Ni}_{2} \mathrm{SbO}_{6}$ ). This feature seems enhanced for $\mathrm{Li}_{3} \mathrm{Ni}_{2} \mathrm{SbO}_{6}$ domains (from $21^{\circ}$ at 
$400{ }^{\circ} \mathrm{C}$ to $20.6{ }^{\circ} \mathrm{C}$ at $700{ }^{\circ} \mathrm{C}$ ), whereas the trend is different for the peak related to $\mathrm{Na}_{3} \mathrm{Ni}_{2} \mathrm{SbO}_{6}$ domains, which slightly shifts to higher angles. The slab thickness contraction (expansion) accounts for lithium (sodium) diffusion into the $\mathrm{Na}_{3} \mathrm{Ni}_{2} \mathrm{SbO}_{6}\left(\mathrm{Li}_{3} \mathrm{Ni}_{2} \mathrm{SbO}_{6}\right)$ alkali layers, in agreement with the above NMR analysis (Figure 3). The underlying mechanism consequently involves a diffusive alkali exchange between domains, respect to a nucleation process for which only a shift due to thermal expansion would have been observed. The slow cooling monitoring shows a similar peak splitting and thus confirms that phase decomposition is thermodynamically favored. To briefly summarize, the Li/Na random distribution mimics an alkali-glass behavior, however confined within a crystalline matrix.

In parallel, DFT calculations have been performed on about 100 structures with $\mathrm{Li}_{1.5} \mathrm{Na}_{1.5} \mathrm{Ni}_{2} \mathrm{SbO}_{6}$ stoichiometry, within random ordering of $\mathrm{Li} / \mathrm{Na}$ in the alkali layer. Figure 7 shows the formation energy of each ordered phase respect to the pure lithiated or sodiated compounds and the variation of the formation energy as a function of the number of Li-Na Nearest Neighbor (NN) bonds. As the relative formation energy is positive, all the random ordered phases are shown to be thermodynamically instable and should decompose following the equation: $\mathrm{Li}_{1.5} \mathrm{Na}_{1.5} \mathrm{Ni}_{2} \mathrm{SbO}_{6} \rightarrow \frac{1}{2} \mathrm{Li}_{3} \mathrm{Ni}_{2} \mathrm{SbO}_{6}+\frac{1}{2} \mathrm{Na}_{3} \mathrm{Ni}_{2} \mathrm{SbO}_{6}$.

The most stable order consist in the out-of-plane ordered/segregated Li/Na phases (at $\sim 3$ meV/atoms) without NN Li-Na, the energy increasing barely linearly with the number of Li-Na NN bonds. In this situation, the stabilization of any ordered phase does not appear as feasible except if configuration entropy, thus $\mathrm{Li} / \mathrm{Na}$ inter-mixing is considered. In fact, the latter can be evaluated within the Stirling approximation to be $\sim 20 \mathrm{meV} /$ atoms at $900{ }^{\circ} \mathrm{C}$ far enough compared to the relative energy between ordered phases. Consequently, the most probable hypothesis consists in an entropically stabilized $\mathrm{Li} / \mathrm{Na}$ intermixing in agreement with the synthesis conditions and thermal behavior, structural refinement and NMR analysis, and characteristic to glassy-like systems. 


\section{Conclusion}

A complete solid-solution from layered $\mathrm{Li}_{3} \mathrm{Ni}_{2} \mathrm{SbO}_{6}$ to $\mathrm{Na}_{3} \mathrm{Ni}_{2} \mathrm{SbO}_{6}$ has been obtained by conventional solid-state synthesis ended by a final quench. On the transition metal layer, the honeycomb $\mathrm{Ni} / \mathrm{Sb}$ cation ordering is maintained all along the solid-solution; however with a partial $\mathrm{Ni} / \mathrm{Sb}$ mixing. Focusing on the alkali layer, configuration entropy leads to $\mathrm{Li} / \mathrm{Na}$ randomly occupied crystallographic positions.

It is believed that other crystalline transition metal oxides exhibiting 2D confined alkali glass behavior could now be prepared thanks to a final quenching step, and thus opening the door towards unexpected physical properties.

\section{Supporting Information}

The Supporting Information section is available free of charge at DOI: xxx.

\section{Notes}

The authors declare no competing financial interest.

\section{Acknowledgment}

The authors thank the French National Research Agency (STORE-EX Labex Project ANR-10LABX-76-01).

\section{Figure and Table captions}


Figure 1. (a) XRD patterns of $\mathrm{Li}_{3-x} \mathrm{Na}_{x} \mathrm{Ni}_{2} \mathrm{SbO}_{6}$ compositions obtained after a final quench, (b) restricted $2 \theta$ window to highlight the honeycomb superstructure peaks, and evolution of (c) the monoclinic cell volume and (d) the slab thickness (calculated by $c x \sin (\beta))$.

Figure 2. Structural hypotheses for the intermediate composition $\mathrm{Li}_{1.5} \mathrm{Na}_{1.5} \mathrm{Ni}_{2} \mathrm{SbO}$. Nickel and antimony cations are green and grey, while lithium and sodium cations are in yellow and orange, respectively.

Figure 3. Solid-state ${ }^{7} \mathrm{Li}$ and ${ }^{23} \mathrm{Na} \mathrm{NMR}$ spectra of as-quenched $\mathrm{Li}_{3-x} \mathrm{Na}_{x} \mathrm{Ni} \mathrm{i}_{2} \mathrm{SbO} \mathrm{O}_{6}$ compositions, with blue dotted lines showing the peak shifting from end members ( $\mathrm{Li}_{3} \mathrm{Ni}_{2} \mathrm{SbO}_{6}$ or $\left.\mathrm{Na}_{3} \mathrm{Ni}_{2} \mathrm{SbO}_{6}\right)$ to intermediate compositions. The symbol (*) accounts for spinning sidebands.

Figure 4: Combined Rietveld refinement of X-ray (top) and neutron (bottom) diffraction patterns of $\mathrm{Li}_{1.5} \mathrm{Na}_{1.5} \mathrm{Ni}_{2} \mathrm{SbO}_{6}$. The red crosses, black continuous line and bottom green line represent the observed, calculated, and difference patterns, respectively. Vertical blue tick bars mark the reflection positions.

Figure 5: (a) Structural model for $\mathrm{Li}_{1.5} \mathrm{Na}_{1.5} \mathrm{Ni}_{2} \mathrm{Sb} \mathrm{O}_{6}$ resulting from the combined $\mathrm{X}$-ray/neutron Rietveld refinement and (b) in-plane views showing the Ni/Sb and Li/Na intermixing.

Figure 6. Thermal evolution of the quenched $\mathrm{Li}_{1.5} \mathrm{Na}_{1.5} \mathrm{Ni}_{2} \mathrm{SbO} \mathrm{O}_{6}$ monitored by in situ XRD. 
Figure 7. (a) Relative formation energy in meV/atom of randomly Na-Li ordered phase respect to the decomposition in pure $\mathrm{Li}_{3} \mathrm{Ni}_{2} \mathrm{SbO}_{6}+\mathrm{Na}_{3} \mathrm{Ni}_{2} \mathrm{SbO} \mathrm{O}_{6}$ phases. All considered phases are not stable versus decomposition since they have positive energy. (b) Relative formation energy in meV/atom as a function of the average number of Na-Li Nearest Neighbor bonds per alkali ions, showing than as more Na-Li are mixed, as high is the energy of the phase.

Table 1: Structural parameters for $\mathrm{Li}_{1.5} \mathrm{Na}_{1.5} \mathrm{Ni}_{2} \mathrm{SbO}$, deduced from the combined Rietveld refinement of the XRD and neutron powder diffraction patterns. 


\section{References}

(1) Shannon, R. D. Revised Effective Ionic Radii and Systematic Studies of Interatomic Distances in Halides and Chalcogenides. Acta Crystallogr. Sect. A Found. Crystallogr. 1976, 32 (5), 751-767. https://doi.org/10.1107/S0567739476001551.

(2) Ng, H. N.; Calvo, C.; Idler, K. L. Crystallographic Studies and Structural Systematics of the C2 c Alkali Metal Metavanadates. J. Solid State Chem. 1979, 27 (3), 357-366. https://doi.org/10.1016/0022-4596(79)90178-6.

(3) Schindler, M.; Hawthorne, F. C.; Alexander, M. A.; Kutluoglu, R. A.; Mandaliev, P.; Halden, N. M.; Mitchell, R. H. Na-Li-[V3O8] Insertion Electrodes: Structures and Diffusion Pathways. J. Solid State Chem. 2006, 179 (8), 2616-2628. https://doi.org/10.1016/j.jssc.2006.05.009.

(4) Yuzyuk, Y. I.; Gagarina, E.; Simon, P.; Reznitchenko, L. A.; Hennet, L.; Thiaudière, D. Synchrotron X-Ray Diffraction and Raman Scattering Investigations of (LixNa1x)NbO3 Solid Solutions: Evidence of the Rhombohedral Phase. Phys. Rev. B Condens. Matter Mater. Phys. 2004, 69 (14), 1-7. https://doi.org/10.1103/PhysRevB.69.144105.

(5) Mishra, S. K.; Krishna, P. S. R.; Shinde, A. B.; Jayakrishnan, V. B.; Mittal, R.; Sastry, P. U.; Chaplot, S. L. High Temperature Phase Stability in Li0.12Na0.88NbO3: A Combined Powder X-Ray and Neutron Diffraction Study. J. Appl. Phys. 2015, 118 (9), 0-7. https://doi.org/10.1063/1.4929645.

(6) Peel, M. D.; Ashbrook, S. E.; Lightfoot, P. Unusual Phase Behavior in the Piezoelectric Perovskite System, $\mathrm{Li}<\mathrm{inf}>\mathrm{X}</ \mathrm{Inf}>\mathrm{Na}<\mathrm{inf}>1-\mathrm{X}</$ Inf $>\mathrm{NbO}<\mathrm{inf}>3</$ Inf $>$. Inorg. Chem. 2013, 52 (15). https://doi.org/10.1021/ic401061t.

(7) Myung, S. T.; Maglia, F.; Park, K. J.; Yoon, C. S.; Lamp, P.; Kim, S. J.; Sun, Y. K. Nickel-Rich Layered Cathode Materials for Automotive Lithium-Ion Batteries: Achievements and Perspectives. ACS Energy Lett. 2017, 2 (1), 196-223. https://doi.org/10.1021/acsenergylett.6b00594.

(8) Assat, G.; Tarascon, J.-M. Fundamental Understanding and Practical Challenges of Anionic Redox Activity in Li-Ion Batteries. Nat. Energy 2018 2018, 1. https://doi.org/10.1038/s41560-018-0097-0.

(9) Nayak, P. K.; Erickson, E. M.; Schipper, F.; Penki, T. R.; Munichandraiah, N.; Adelhelm, P.; Sclar, H.; Amalraj, F.; Markovsky, B.; Aurbach, D. Review on Challenges and Recent Advances in the Electrochemical Performance of High Capacity Li- and Mn-Rich Cathode Materials for Li-Ion Batteries. Adv. Energy Mater. 2018, 8 (8), 1-16. https://doi.org/10.1002/aenm.201702397.

(10) Shilov, G. V.; Nalbandyan, V. B.; Volochaev, V. A.; Atovmyan, L. O. Crystal Growth and Crystal Structures of the Layered Ionic Conductors-Sodium Lithium Titanium Oxides. Int. J. Inorg. Mater. 2000, 2 (5), 443-449. https://doi.org/10.1016/S14666049(00)00050-7.

(11) Matsumura, T.; Kanno, R.; Gover, R.; Kawamoto, Y.; Kamiyama, T.; Mitchell, B. J. Synthesis, Structure and Physical Properties of $\mathrm{Li}_{x} \mathrm{Na}_{1-\mathrm{x}} \mathrm{NiO}_{2}$. Solid State Ionics 2002, 
$152-153,303-309$.

(12) Holzapfel, M.; De Brion, S.; Darie, C.; Bordet, P.; Chappel, E.; Chouteau, G.; Strobel, P.; Sulpice, A.; Nu?ez-Regueiro, M. D. Decoupling of Orbital and Spin Degrees of Freedom in $\mathrm{Li}_{1-x} \mathrm{Na}_{x} \mathrm{NiO}_{2}$. Phys. Rev. B Condens. Matter Mater. Phys. 2004, 70 (13).

(13) Holzapfel, M.; Darie, C.; Bordet, P.; Chappel, E.; Núñez-Regueiro, M. D.; Diaz, S.; De Brion, S.; Chouteau, G.; Strobel, P. Mixed Layered Oxide Phases Na XLi 1-XNiO 2: A Detailed Description of Their Preparation and Structural and Magnetic Identification. Solid State Sci. 2005, 7 (5), 497-506. https://doi.org/10.1016/j.solidstatesciences.2004.10.046.

(14) Delmas, C.; Fouassier, C.; Hagenmuller, P. Structural Classification and Properties of the Layered Oxides. Phys. $B+C$ 1980, 99 (1? 4$), 81-85$.

(15) Politaev, V. V; Nalbandyan, V. B.; Petrenko, A. A.; Shukaev, I. L.; Volotchaev, V. A.; Medvedev, B. S. B. Mixed Oxides of Sodium, Antimony (5+) and Divalent Metals (Ni, Co, Zn or Mg). J. Solid State Chem. 2010, 183 (3), 684-691.

(16) Schmidt, W.; Berthelot, R.; Sleight, A. W.; Subramanian, M. A. Solid Solution Studies of Layered Honeycomb-Ordered Phases $\mathrm{O}<\mathrm{inf}>3</ \mathrm{Inf}>$ $\mathrm{Na}<\inf >3</ \mathrm{Inf}>\mathrm{M}<$ inf $>2</ \mathrm{Inf}>\mathrm{SbO}<\inf >6</ \mathrm{Inf}>(\mathrm{M}=\mathrm{Cu}, \mathrm{Mg}, \mathrm{Ni}, \mathrm{Zn})$. J. Solid State Chem. 2013, 201. https://doi.org/10.1016/j.jssc.2013.02.035.

(17) Ma, J.; Bo, S. H.; Wu, L.; Zhu, Y.; Grey, C. P.; Khalifah, P. G. Ordered and Disordered Polymorphs of $\mathrm{Na}(\mathrm{Ni}<$ inf $>2 / 3</ \mathrm{Inf}>\mathrm{Sb}<\mathrm{inf}>1 / 3</ \mathrm{Inf}>) \mathrm{O}<$ inf $>2</ \mathrm{Inf}>$ : HoneycombOrdered Cathodes for Na-Ion Batteries. Chem. Mater. 2015, 27 (7), 2387-2399. https://doi.org/10.1021/cm504339y.

(18) Zvereva, E. A.; Evstigneeva, M. A.; Nalbandyan, V. B.; Savelieva, O. A.; Ibragimov, S. A.; Volkova, O. S.; Medvedeva, L. I.; Vasiliev, A. N.; Klingeler, R.; Buechner, B. Monoclinic Honeycomb-Layered Compound Li 3Ni 2SbO 6: Preparation, Crystal Structure and Magnetic Properties. Dalt. Trans. 2012, 41 (2), 572-580. https://doi.org/10.1039/c1dt11322d.

(19) Kresse, G.; J. Furthm“ Uller. Efficient Iterative Schemes for Ab Initio Total-Energy Calculations Using a Plane-Wave Basis Set. Phys. Rev. B 1996, 54 (16), 11169-11186.

(20) G.Kresse, D. J. From Ultrasoft Pseudopotentials to the Projector Augmented-Wave Method. Phys. Rev. B 1999, 59 (3), 1758-1775. https://doi.org/10.1103/PhysRevB.59.1758.

(21) Perdew, J. P.; Burke, K.; Ernzerhof, M. Generalized Gradient Approximation Made Simple. Phys. Rev. Lett. 1996, 77 (18), 3865-3868. https://doi.org/10.1103/PhysRevLett.77.3865.

(22) Dudarev, S. L.; Botton, G. A.; Savrasov, S. Y.; Humphreys, C. J.; Sutton, A. P. Electron-Energy-Loss Spectra and the Structural Stability of Nickel Oxide:\&\#8194;\&\#8194;An LSDA+U Study. Phys. Rev. B 1998, 57 (3), 1505-1509.

(23) Berthelot, R.; Pollet, M.; Carlier, D.; Delmas, C. Reinvestigation of the OP4$(\mathrm{Li} / \mathrm{Na}) \mathrm{CoO} 2-\mathrm{Layered}$ System and First Evidence of the $(\mathrm{Li} / \mathrm{Na} / \mathrm{Na}) \mathrm{CoO} 2$ Phase with OPP9 Oxygen Stacking. Inorg. Chem. 2011, 50 (6), 2420-2430. 
https://doi.org/10.1021/ic102218w.

(24) Berthelot, R.; Carlier, D.; Delmas, C. Electrochemical Investigation of the P2$\mathrm{Na}<\mathrm{inf}>\mathrm{x}</$ Inf $>\mathrm{CoO}<$ inf $>2</$ Inf $>$ phase Diagram. Nat. Mater. 2011, 10 (1), 74-80. https://doi.org/10.1038/nmat2920.

(25) Blangero, M.; Decourt, R.; Carlier, D.; Ceder, G.; Pollet, M.; Doumerc, J.-P.; Darriet, J.; Delmas, C. First Experimental Evidence of Potassium Ordering in Layered K4Co7O14. Inorg. Chem. 2005, 44 (25), 9299-9304.

(26) Br?ger, J.; Jiang, M.; Dupr?, N.; Meng, Y. S.; Shao-Horn, Y.; Ceder, G.; Grey, C. P. High-Resolution X-Ray Diffraction, DIFFaX, NMR and First Principles Study of Disorder in the Li2MnO3-Li[Ni1/2Mn1/2]O2 Solid Solution. J. Solid State Chem. 2005, 178 (9), 2575-2585.

(27) Zvereva, E. A.; Evstigneeva, M. A.; Nalbandyan, V. B.; Savelieva, O. A.; Ibragimov, S. A.; Volkova, O. S.; Medvedeva, L. I.; Vasiliev, A. N.; Klingeler, R.; Buechner, B. Monoclinic Honeycomb-Layered Compound Li3Ni2SbO6: Preparation, Crystal Structure and Magnetic Properties. Dalt. Trans. 2012, 41 (2), 572-580.

(28) McCalla, E.; Abakumov, A.; Rousse, G.; Reynaud, M.; Sougrati, M. T.; Budic, B.; Mahmoud, A.; Dominko, R.; Van Tendeloo, G.; Hermann, R. P.; et al. Novel Complex Stacking of Fully-Ordered Transition Metal Layers in Li4FeSbO6 Materials. Chem. Mater. 2015, 27 (5), 1699-1708. https://doi.org/10.1021/cm504500a. 
Figure 1

a)

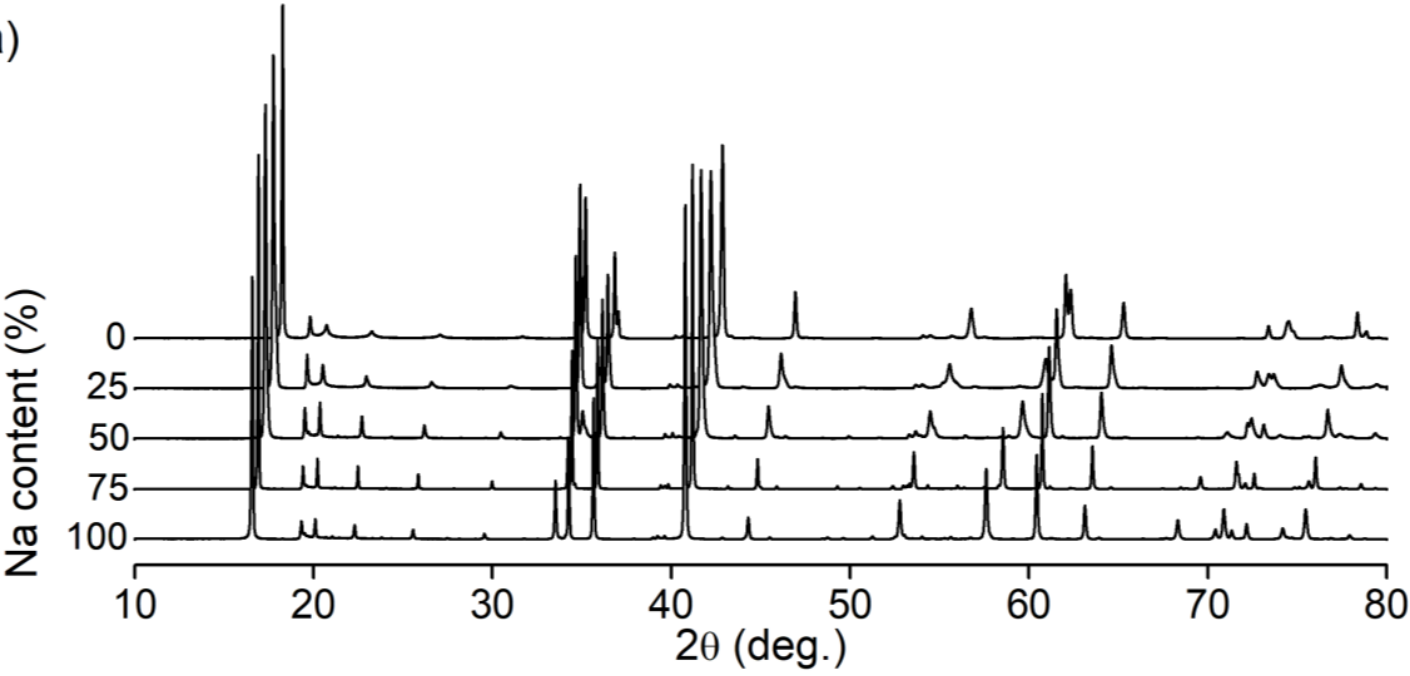

b)

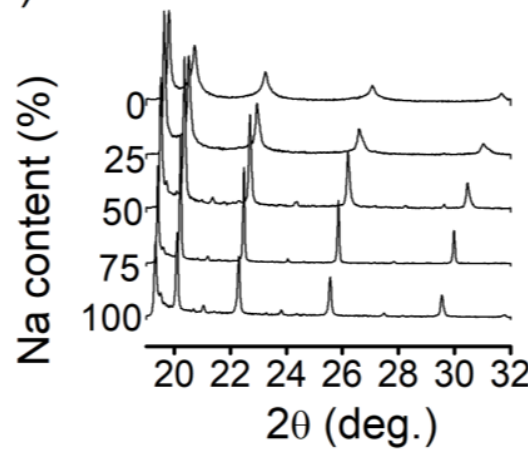

c)

d)
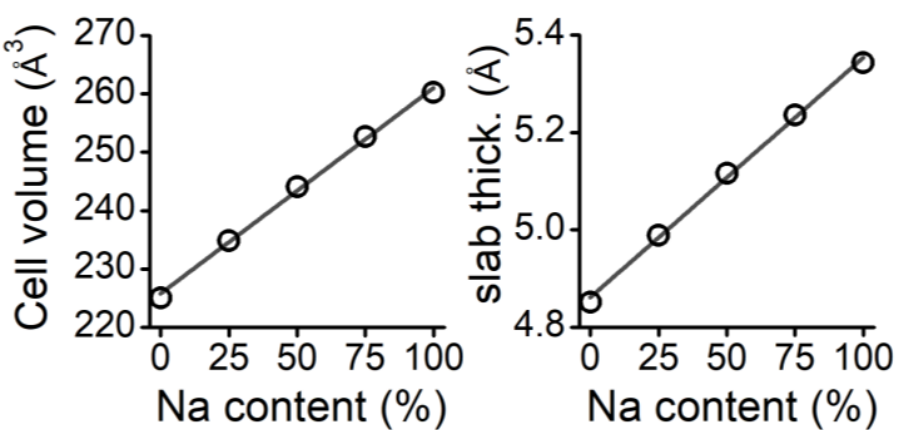

Figure 2

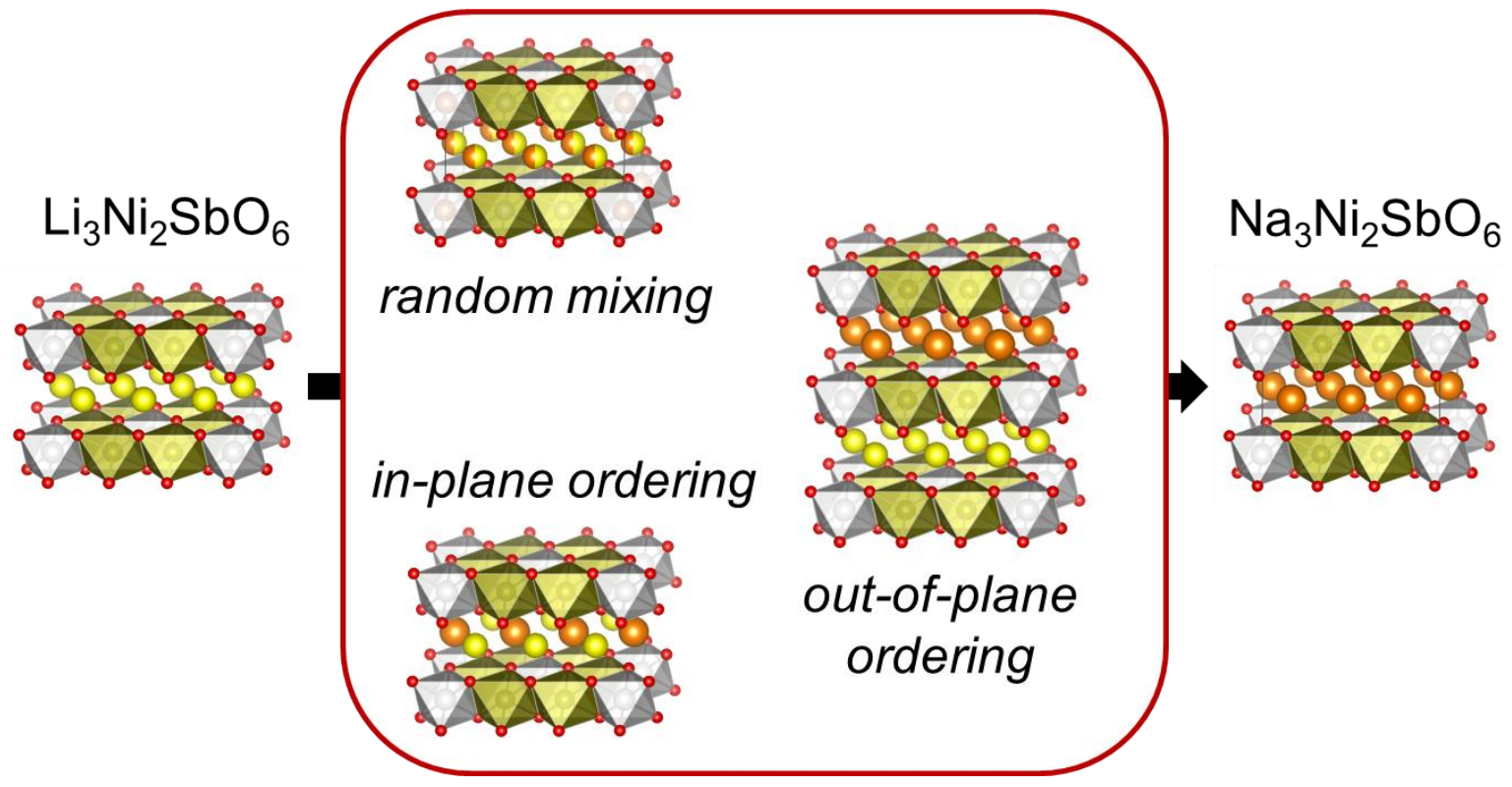


Figure 3
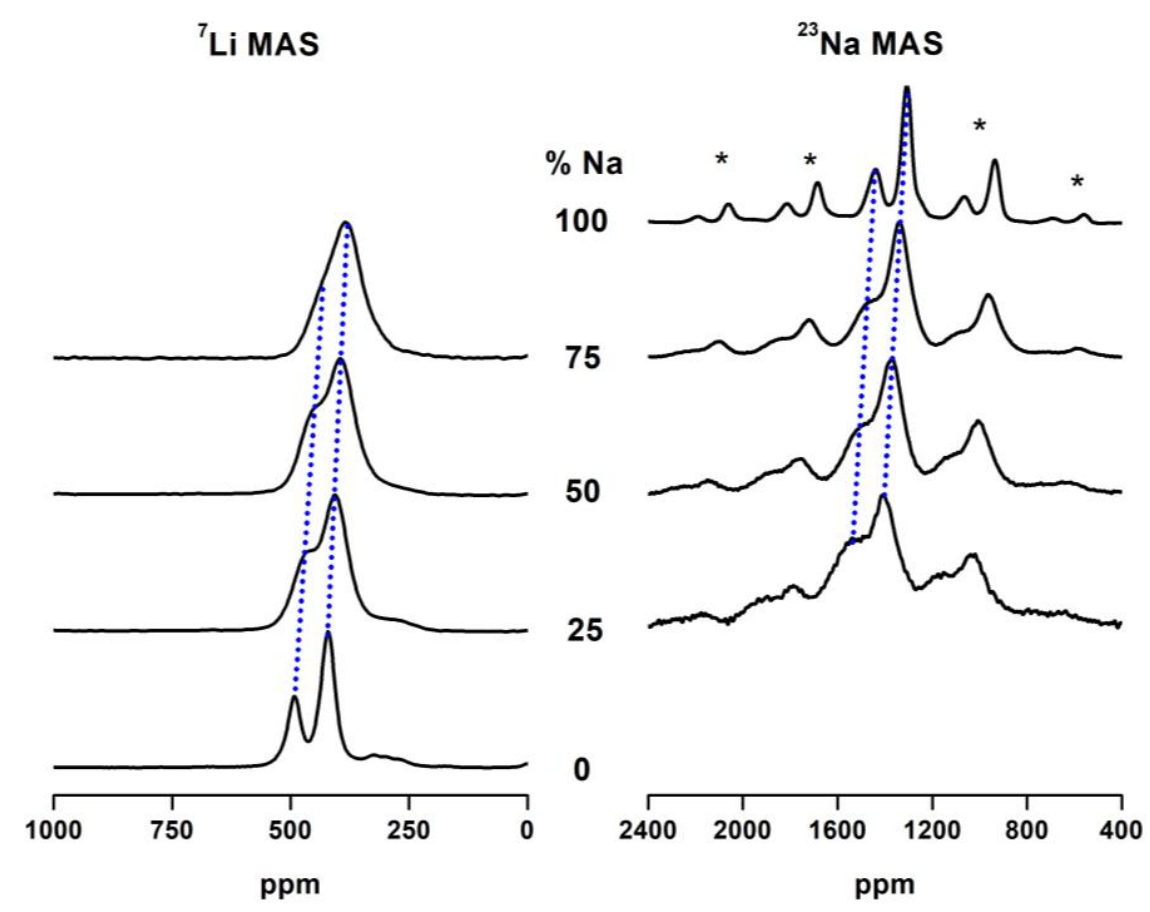

Figure 4
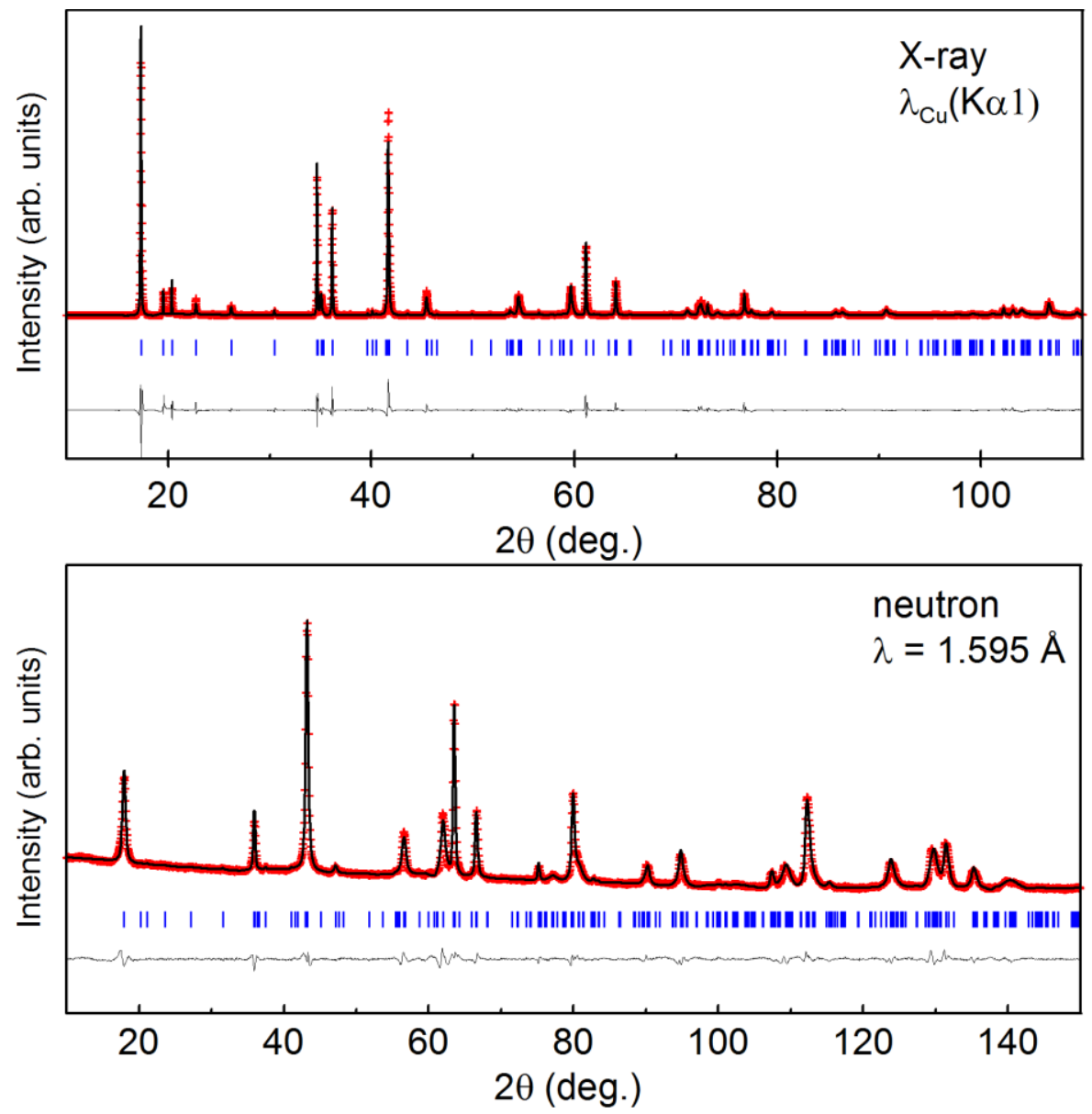

Page 20 
Figure 5

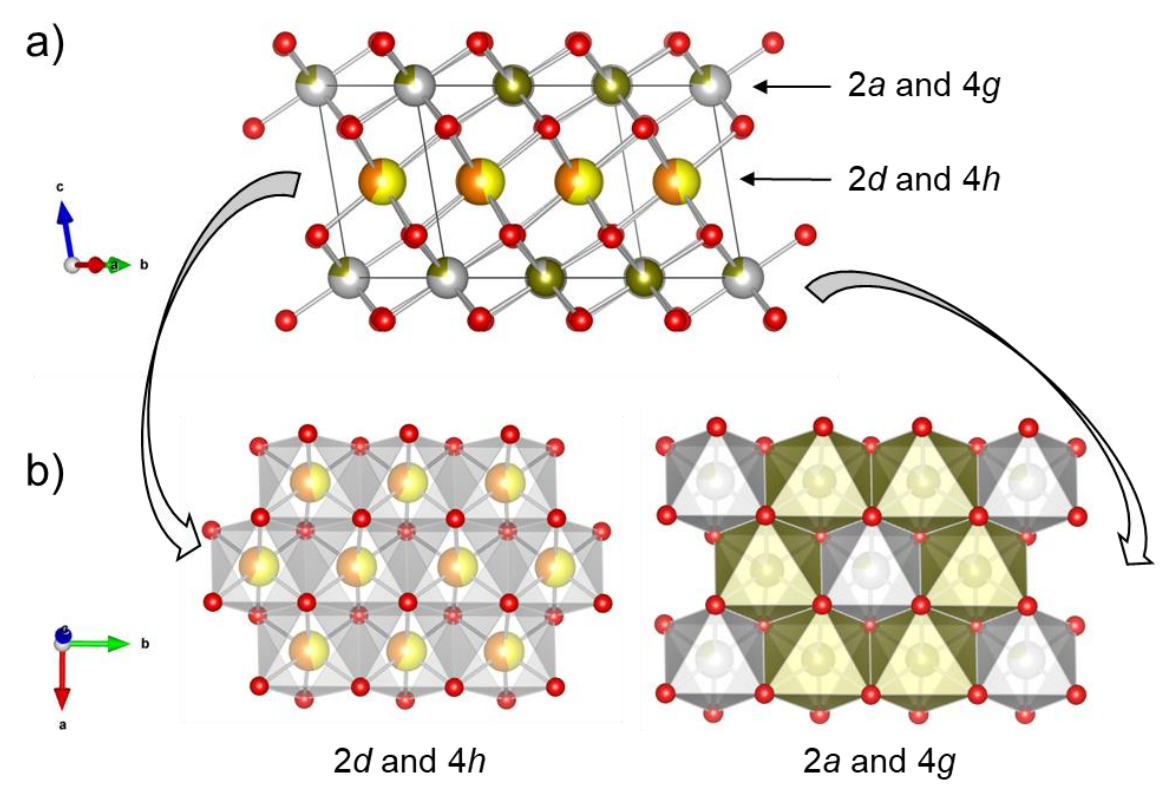

Figure 6

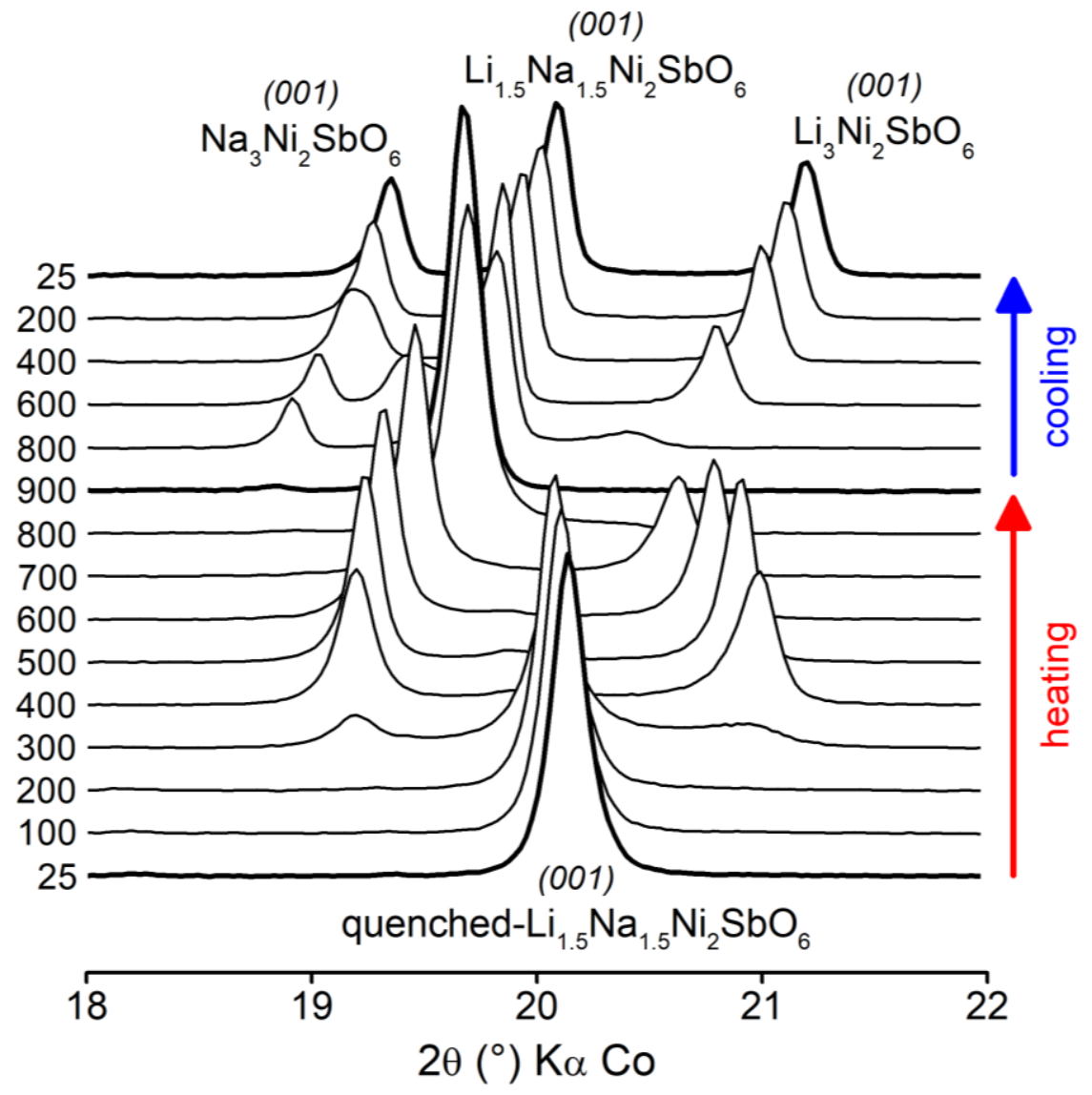




\section{Figure 7}

a)

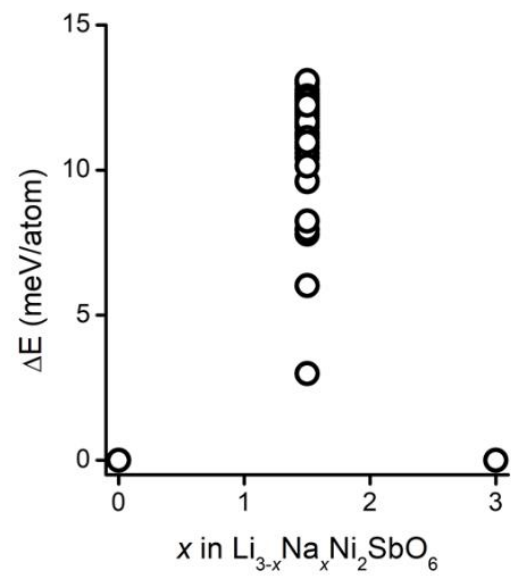

b)

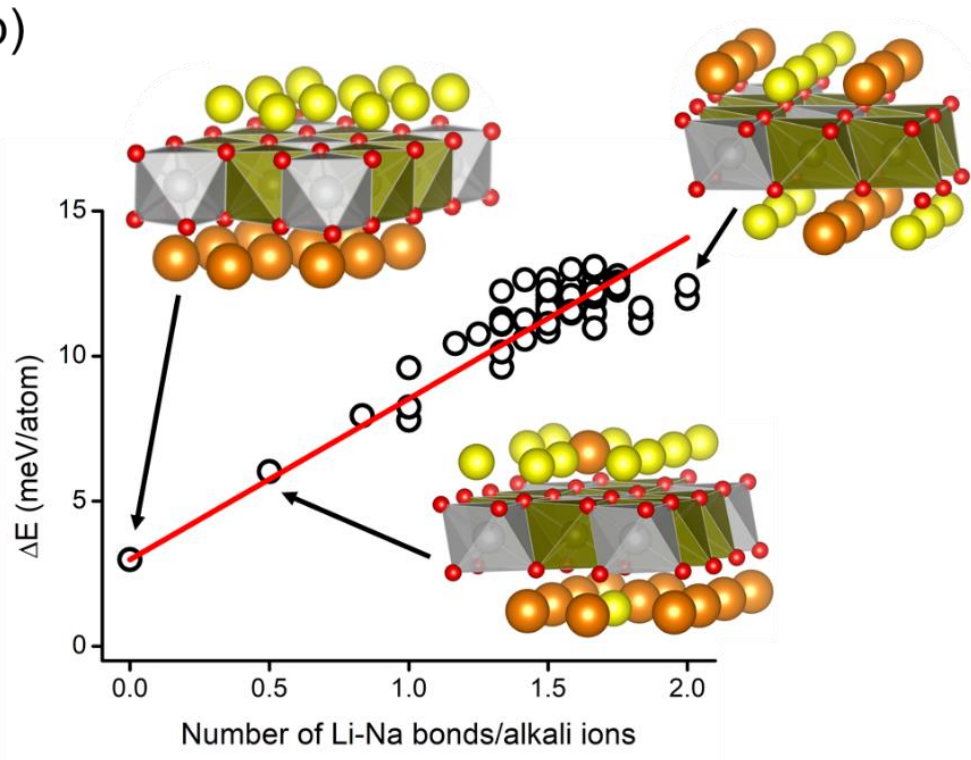

\section{Table 1}

\section{$\mathrm{Li}_{1.5} \mathrm{Na}_{1.5} \mathrm{Ni}_{2} \mathrm{SbO}_{6}$}

Space Group: $C 2 / m$

$a=5.2434(2) \AA, b=9.0997(3) \AA, c=5.4034(6) \AA, \beta=108.794(8) \mathrm{deg}$.

$V=243.641(5) \AA^{3}$

\begin{tabular}{|c|c|c|c|c|c|c|}
\hline Atom & $\begin{array}{c}\text { Wyckoff } \\
\text { site }\end{array}$ & $x$ & $y$ & $z$ & $\mathbf{B}_{\text {iso }}\left(\AA^{2}\right)$ & Occ \\
\hline $\mathrm{O} 1$ & $4 i$ & $0.736(2)$ & 0 & $0.209(2)$ & $0.50(6)$ & 1 \\
\hline $\mathrm{O} 2$ & $8 j$ & $0.2351(16)$ & $0.1584(9)$ & $0.2230(12)$ & $0.50(6)$ & 1 \\
\hline $\mathrm{Ni1} / \mathrm{Sb} 1$ & $4 g$ & 0 & $0.3330(4)$ & 0 & $0.02(3)$ & $\begin{array}{l}0.882(2)(\mathrm{Ni}) \\
0.118(2)(\mathrm{Sb})\end{array}$ \\
\hline $\mathrm{Sb} 2 / \mathrm{Ni} 2$ & $2 a$ & 0 & 0 & 0 & $0.02(3)$ & $\begin{array}{l}0.764(2)(\mathrm{Sb}) \\
0.236(2)(\mathrm{Ni})\end{array}$ \\
\hline $\mathrm{Li} 1 / \mathrm{Na} 1$ & $4 h$ & 0 & $0.1707(15)$ & $1 / 2$ & $0.48(13)$ & $\begin{array}{c}0.461(8)(\mathrm{Li}) \\
0.539(8)(\mathrm{Na})\end{array}$ \\
\hline $\mathrm{Li} 2 / \mathrm{Na} 2$ & $2 d$ & 0 & $1 / 2$ & $1 / 2$ & $0.48(13)$ & $\begin{array}{c}0.578(8)(\mathrm{Li}) \\
0.422(8)(\mathrm{Na})\end{array}$ \\
\hline
\end{tabular}

XRD: Bragg R-factor $=8.61 \%$, Rf-factor $=6.23 \%$

Neutrons: Bragg R-factor $=2.81 \%$, Rf-factor $=2.30 \%$ 